\title{
Whitefly, aphids and thrips attack on cabbage
}

\author{
Germano Leão Demolin Leite ${ }^{(1)}$, Marcelo Picanço ${ }^{(2)}$, Gulab Newandram Jham ${ }^{(3)}$ and Márcio Dionízio Moreira(2)
}

(1)Universidade Federal de Minas Gerais, Núcleo de Ciências Agrárias, Dep. de Agropecuária, Caixa Postal 135, CEP 39404-006 Montes Claros, MG. E-mail: gldleite@nca.ufmg.br (2)Universidade Federal de Viçosa (UFV), Dep. de Biologia Animal, CEP $36571-000$ Viçosa, MG. E-mail: picanco@mail.ufv.br ${ }^{(3)}$ UFV, Dep.de Química. E-mail: gulab@mail.ufv.br

\begin{abstract}
The objective of this work was to investigate the relationships between predators and parasitoids, leaf chemical composition, levels of leaf nitrogen and potassium, total rainfall, relative humidity, daylight and median temperature on the intensity of whitefly, aphid, and thrips attack on cabbage. Whitefly, aphids and thrips population tended to proliferate in the final stage of plant or reached a peak population about 40 days after plantation. The whitefly and thrips tended to increase with an increase in the median temperature. A dependence of Cheiracanthium inclusum and Adialytus spp. populations on whitefly and aphids populations, respectively, was observed. No significant effect was detected between $\mathrm{K}$ and nonacosane leaf content and aphid population. However, an increase in leaf $\mathrm{N}$ content was followed by a decrease of this insect population. No significant relation was observed between leaf $\mathrm{N}$, $\mathrm{K}$ and nonacosane and whitefly and thrips populations. Highest nonacosane levels were observed in plants 40 days after transplant, and relative humidity correlated negatively with nonacosane. Natural enemies, especially the parasitoid Adialytus spp. and the spiders can be useful controlling agents of the whitefly and aphids in cabbage. Median temperature can increase whitefly and thrips populations.
\end{abstract}

Index terms: Bemisia tabaci, Brevicoryne brassicae, Thrips tabaci, Brassica oleracea, temperature, nonacosane.

\section{Ataque de mosca-branca, pulgões e tripes em repolho}

Resumo - O objetivo deste trabalho foi investigar as relações entre predadores, parasitóides, composição química foliar, níveis de nitrogênio e de potássio foliar, pluviosidade, umidade relativa, insolação e temperatura média na intensidade de ataque de mosca-branca, pulgão e tripes em repolho. As populações de mosca-branca, pulgões e tripes tenderam a aumentar no final do cultivo ou apresentaram pico 40 dias depois do transplantio. As populações de mosca-branca e tripes tenderam a aumentar sob temperaturas mais elevadas. As populações de Cheiracanthium inclusum e Adialytus spp. dependiam das populações de mosca-branca e pulgões, respectivamente. Não se detectou efeito significativo entre os níveis foliares de $\mathrm{K}$ e nonacosano e a população de pulgões; entretanto, aumento nos níveis de $\mathrm{N}$ foliar resultou em menor população da praga. Não se detectou relação significativa entre os níveis foliares de $\mathrm{N}$, K e nonacosano e as populações de mosca-branca e de tripes. Altos níveis foliares de nonacosano foram observados 40 dias depois do transplantio, e a umidade relativa correlacionou-se negativamente com os níveis de nonacosano. Inimigos naturais, especialmente o parasitóide Adialytus spp. e as aranhas, podem ser agentes de controle biológico eficazes de mosca-branca e pulgões em repolho. A temperatura pode aumentar as populações de mosca-branca e tripes.

Termos para indexação: Bemisia tabaci, Brevicoryne brassicae, Thrips tabaci, Brassica oleracea, temperatura, nonacosano.

\section{Introduction}

Cabbage Brassica oleracea var. capitata Linneu, cultivated worldwide, is attacked by pests such as whitefly Bemisia tabaci (Gennadius) (Hemiptera: Aleyrodidade), aphid Brevicoryne brassicae (Linneu)
(Hemiptera: Aphididae) and Thrips tabaci Lindeman (Thysanoptera: Thripidae). These insects weaken the plant by sucking the sap and introducing toxins into the plant's vascular system, coating the leaf with honeydew, facilitating the growth of soot mold, and producing white streaking disorder, leaf chlorosis and leaf wrinkling. 
The control of these insects consists primarily of blanket use of insecticides. The frequency of insecticide applications is determined by the degree of damage which is heavily influenced by cosmetic considerations (Filgueira, 2000). One of the principal reasons for this extensive application is the lack of information on factors affecting insect population. Such information could facilitate the prediction of insect attack, which in turn could reduce economic losses.

Several factors such as climatic conditions (Gonçalves, 1997), crop fertility status, age and growth rate (Marschner, 1995), natural enemies and leaf chemical composition (Eigenbrode \& Pillai, 1998; Leite et al., 2005) can influence insect population in plants.

The objective of this work was to correlate intensity of predators and parasitoids, leaf chemical composition, levels of leaf nitrogen and potassium, total rainfall, relative humidity, daylight and median temperature with the intensity of B. tabaci, B. brassicae and T. tabaci attack on cabbage under field conditions.

\section{Material and Methods}

The experiment was conducted using six cabbage plantations of Brassica oleraceae var. capitata genotype "Saturno", planted 50 to $200 \mathrm{~m}$ apart from each other, from October 1998 to November 1999, in Viçosa, MG, Brazil. Cabbage plantations 1, 3, 4 and 6 were planted in October 1998, February 1999, March 1999 and August 1999, respectively; they were first evaluated after ten days. Plantations 2 and 5 were planted in January 1999, and June 1999, respectively, and were first evaluated after 30 and 40 days, respectively.

The cabbage cultivars comprised 1,600 plants spaced $0.4 \mathrm{~m}$ apart within rows and $0.8 \mathrm{~m}$ between rows. The six peripheric rows and the first 15 plants on each side of the row formed an outer border and the remaining plantation was considered the useful area. Cultural practices were followed throughout the cultivation period as described for cabbage (Filgueira, 2000). Plants were not pulverized with pesticides.

The beating tray method (Miranda et al., 1998) was used to estimate weekly the number of adults of B. tabaci, T. tabaci, predators and parasitoids. Direct counting was applied in adults and nymphs of B. brassicae (Leite et al., 2005) present in one leaf from each of 10 plants per plantation. The beating tray method consisted in beating the first fully expanded leaf, which is next to the cabbage head, in a $34 \times 26 \times 5 \mathrm{~cm}$ white tray and counting the insects.

Insects lodged into the tray were collected, using an aspirator or tweezers, and held individually, in $8 \times 2 \mathrm{~cm}$ glass flasks containing $70 \%$ ethanol, for identification. Nymphal B. tabaci parasitism index in the cabbage plant was evaluated weekly using 40x magnifying lens. One expanded leaf, close to the cabbage head, from each of the ten plants per plantation was collected, conditioned in transparent white plastic bags, sealed and transported to the laboratory, where the insects were counted. For each sample, 18 fields in the median part, field equidistant between the median vein and the margin, were analyzed.

To identify compounds soluble in hexane, fully expanded leave, close to the cabbage head, from 12 plants per plantation (plantations evaluated: 3,4 , and 6) were collected monthly. The hexane extract preparation, the analyzis by gas chromatography/mass spectrometry (GC/MS) and identification as well as quantification of nonacosane were carried out as described by Leite et al. (2005).

In order to determine leaf $\mathrm{N}$ and $\mathrm{K}$, an expanded leaf, next to the head, from 12 plants per plantation (plantations evaluated: 3,4 , and 6) was collected monthly and transported to the laboratory. The leaves were placed in Kraft paper bags, dried in a forced air circulation oven at $67^{\circ} \mathrm{C}$, for three days, and then grounded in a Wiley mill (20 mesh). K was determined with Flame Photometer (Coleman, Model 22) and $\mathrm{N}$ was analyzed by the Nessler method. Three evaluations (four leaves $=$ one evaluation) were made for each monthly collection of the three plantations.

Viçosa climatic data - median temperature (minimum + maximum/2), daylight, total rainfall and relative humidity were collected daily, at Estação Climatológica Principal, Universidade Federal de Viçosa (UFV) (INMET/ 5oDISME/UFV), during the experiment. Data were submitted to regression analysis $(\mathrm{p}<0.05)$.

\section{Results and Discussion}

The whitefly, aphids and thrips population tended to an exponential rise increase in the final phase of the plant or reached a peak in about 40 days after plantation (Figure $1 \mathrm{~A}, \mathrm{~B}$ and $\mathrm{C}$ ), when cabbage head was being formed. Simmons (1999) reported increase of B. tabaci population in pumpkin, eggplant, bean, zucchini and sweet pepper, as plants aged. 

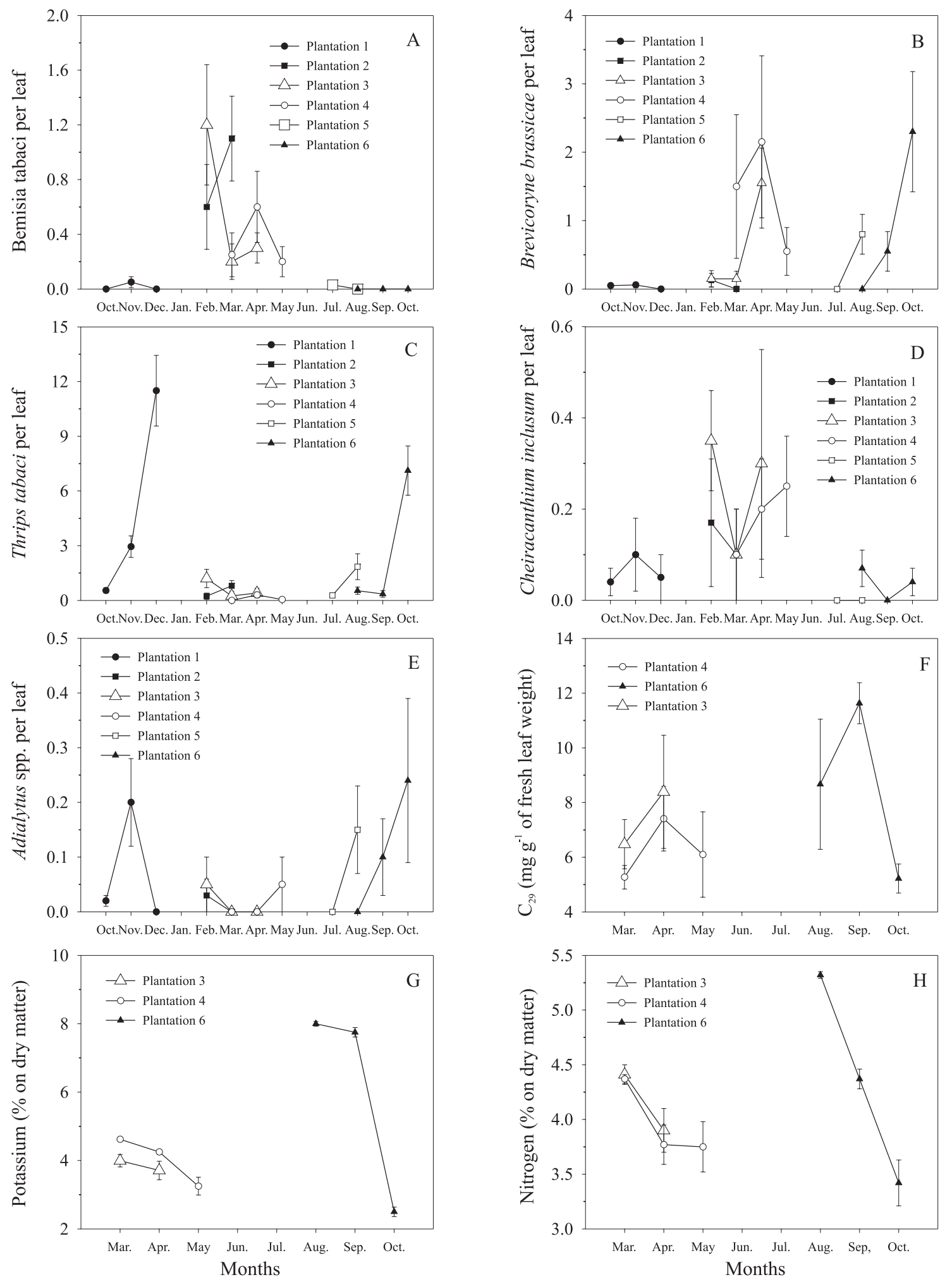

Figure 1. Flutuations in populations of Bemisia tabaci (adults) (A), Brevicoryne brassicae (adults + nymphs) (B), Thrips tabaci (adults + nymphs) (C), Cheiracanthium inclusum (adults + nymphs) (D) and Adialytus spp. (adults) $(\mathrm{E})$, and nonacosane $(\mathrm{F})$, potassium $(\mathrm{G})$ and nitrogen $(\mathrm{H})$ content in cabbage. The vertical bars indicate standard errors of the mean. 
Some aphid species, such as Myzus persicae (Sulzer), which is considered initial pest, could induce undesirable changes in the host plant physiology during development (Noortje \& Lindhout, 1992). Morphophysiological changes due to plant age, crop phenology and nutritional factors were reported to affect whitefly, aphid, and thrips populations in several crops (Hooks et al., 1998; Leite et al., 2005).

A dependence of Cheiracanthium inclusum (Hentz) (Miturgidae) $(0.12 \pm 0.03$ per leaf) and Adialytus spp. (Hymenoptera: Braconidae) $(0.07 \pm 0.03$ per leaf $)$ populations on whitefly and aphids populations, respectively, was observed (Figures $1 \mathrm{D}$ and $\mathrm{E}$ and $2 \mathrm{~A}$ and $\mathrm{B}$ ). Other natural enemies such as Encarsia sp. (Hymenoptera: Aphelinidae) $(0.01 \pm 0.01$ per leaf), Eulophidae (Hymenoptera) $(0.03 \pm 0.01$ per leaf) and Syrphus sp. (Diptera: Syrphidae) $(0.01 \pm 0.01$ per leaf) did not correlate $(\mathrm{p}>0.05)$ with whitefly, thrips and aphids populations, and no parasite-infected whitefly nymphs were detected, probably due to low number of these natural enemies.

The parasitoid Adialytus spp. and spiders were reported as limiting factors for population increases of $B$. brassicae and B. tabaci. In several plants, a positive effect of Braconidae, Encarsia sp., Eulophidae, predatory ladybugs (Coleoptera), Anthocoridae (Heteroptera), Syrphidae (Diptera), spiders, Condylostylus spp. (Diptera: Dolichopodidae) and entomopathogenic fungi was observed (Heinz \& Nelson, 1996; Hooks et al., 1998; Tagashira \& Hirose, 2001). Stansly et al. (1997) reported that natural enemy population tended to increase at the end of the cultivar cycle. This led to a decrease in plant quality, accompanied by decreases in insect pest with its natural enemy population.

Hence, to reduce whitefly, aphids and thrips populations, it is necessary to colonize, quickly, cabbage plantations with natural enemies (e.g. refuge crops and weedy margins), in order to achieve success on biological control; and to utilize insecticides, always selective, only when these pests reached nominal thresholds.

Several peaks were recorded on GC/MS analysis of the hexane extracts but only nonacosane (Similarity Index $>90 \%$ ) was identified by the mass spectra database. Among the factors studied, only relative humidity correlated negatively with nonacosane (Figure $2 \mathrm{C}$ ). Highest nonacosane levels were observed in plants, 40 days after transplant (Figure $1 \mathrm{~F}$ ).
A small positive influence of nonacosane (nonsignificant effect, $\mathrm{p}>0.05$ ), principal component of wax in Brassicaceae (Eigenbrode \& Pillai, 1998), was noted on whitefly, aphids and thrips populations in cabbage. Kale genotypes comprising a high content of leaf wax are more susceptible to B. brassicae attack but more resistant to M. persicae (Paula et al., 1995; Leite et al., 2005). However, the accepted hypothesis is that the wax components rarely deter herbivore attack and more commonly stimulate them (Woodhead \& Chapman, 1986), such as observed here.

No significant effect $(\mathrm{p}>0.05)$ was detected between $\mathrm{K}$ leaf content and aphid population, however, an increase in leaf $\mathrm{N}$ content was accompanied by a decrease in the population of this insect (Figure $2 \mathrm{D}$ ). No significant relation ( $p>0.05$ ) was observed between $\mathrm{N}$ and $\mathrm{K}$ foliar content with whitefly and thrips. An increase in plant age was accompanied by a decreased leaf $\mathrm{K}$ and $\mathrm{N}$ content (Figures $1 \mathrm{G}$ and $\mathrm{H}$ and $2 \mathrm{E}$ and F). High $\mathrm{N}$ levels have been associated with whitefly, aphids and thrips infestation in several crops (Brodbeck et al., 2001; Cisneros \& Godfrey, 2001; Nevo \& Coll, 2001). N can be a key factor for increasing the aphids in cotton (Cisneros \& Godfrey, 2001).

Leite et al. (2005) did not find effect of leaf N and K on the intensity of B. tabaci, T. tabaci and B. brassicae on kale. It was not possible to detect the effect of leaf $\mathrm{K}$ levels in cabbage on whitefly, aphids and thrips populations, and the effect of leaf $\mathrm{N}$ on whitefly and thrips populations, maybe due to small variation of this nutrient in the leaves during the experimental period. However, a negative effect of leaf $\mathrm{N}$ was noticed on the aphid density, but this effect seems to be related to plant age as $\mathrm{N}$ decreases with plant age and in general aphid population increases towards the end of plant cycle.

No significant $(\mathrm{p}>0.05)$ relation was observed between the median temperature and aphids and thrips, however a higher number of whitefly adults was observed in periods of higher average temperature (Figures $2 \mathrm{G}$ and $3 \mathrm{~A}$ ). Total rainfall, daylight and relative humidity did not significantly $(\mathrm{p}>0.05)$ relate whitefly and aphids; and total rainfall and relative humidity for thrips (Figures $1 \mathrm{~A}, \mathrm{~B}$ and $\mathrm{C}$ and $3 \mathrm{~B}, \mathrm{C}$ and $\mathrm{D}$ ). A smaller number of thrips was observed in periods of higher daylight (Figure $2 \mathrm{H}$ ).

Whitefly and thrips population tended to increase with an increase in mean temperature in this work, despite higher occurrence of thrips in periods of smaller daylight. This seems to be an indirect relationship with temperature 



Figure 2. Relationships between $C$. inclusum (adults + nymphs) with B. tabaci (adults) (A); Adialytus spp. (adults) with B. brassicae (adults + nymphs) (B); nonacosane content with relative humidity (C); B. brassicae (adults + nymphs) with nitrogen (D); potassium (E) and nitrogen (F) with plant age; B. tabaci (adults) with median temperature $(\mathrm{G}) ;$ T. tabaci (adults + nymphs) with daylight $(\mathrm{H})$. 

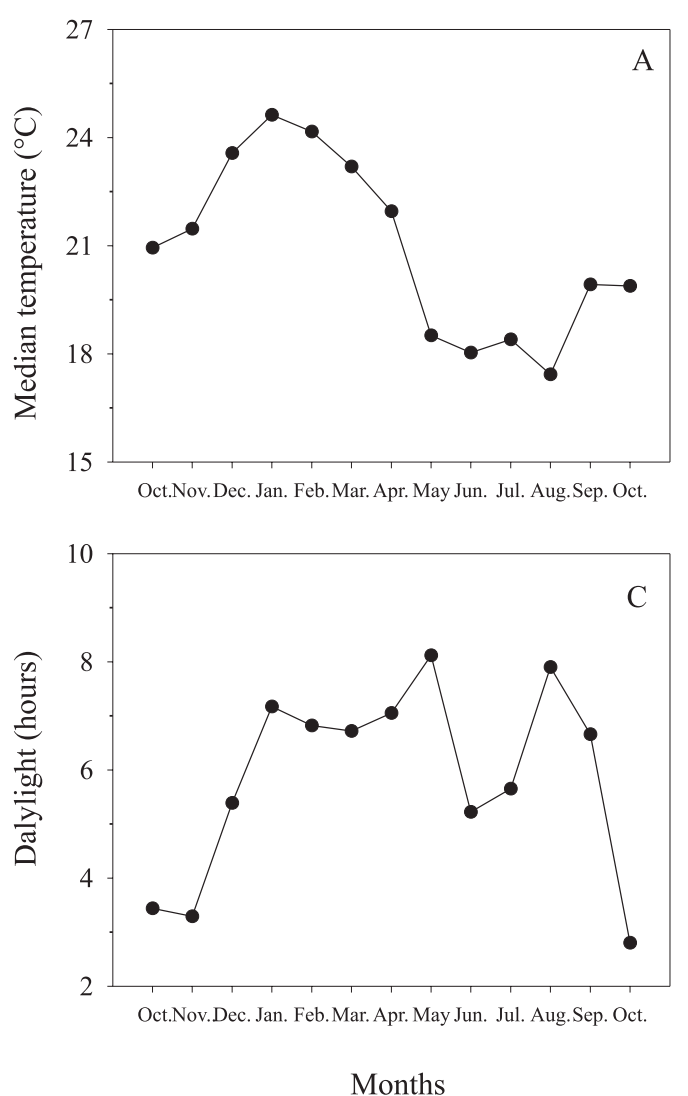
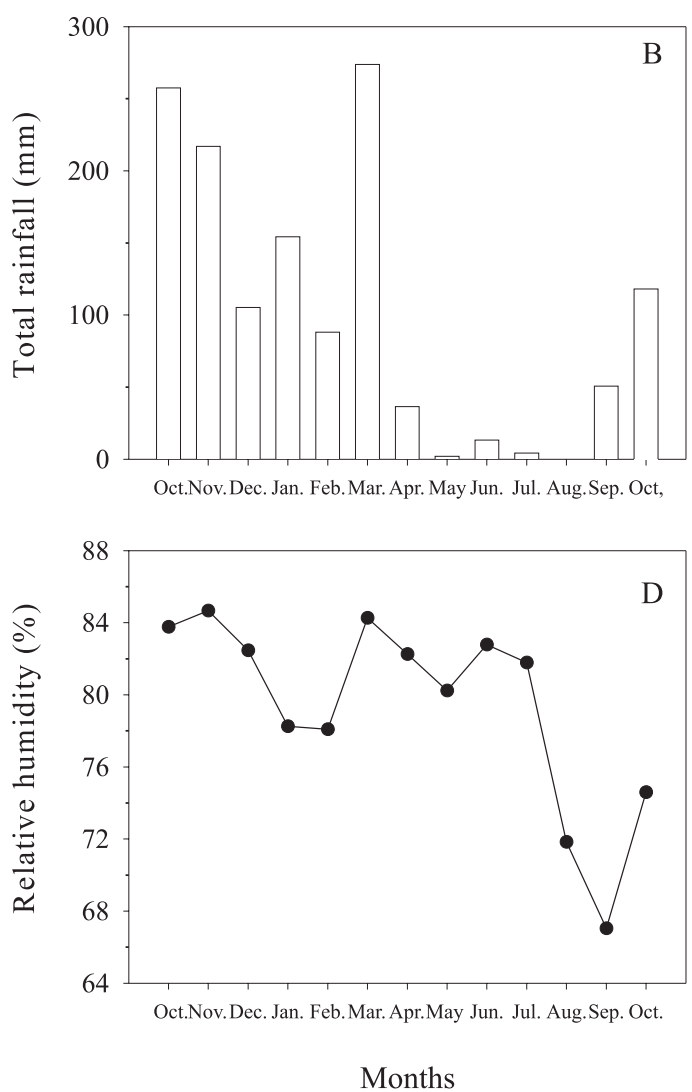

Figure 3. Median temperature (A), total rainfall distribution (B), daylight (C), and relative humidity (D), during experimental period.

because the rainy season (convective rain) occurs during periods of high temperature and, consequently, small daylight. Increases in temperature favor the $B$. tabaci and T. tabaci populations while heavy rain and high humidity are deleterious to these insects (Gonçalves, 1997; Leite et al., 2005). On the other hand, high temperatures and rainfall are important as they can produce high mortality of aphids in field (Nakata, 1995; Leite et al., 2005).

\section{Conclusions}

1. Natural enemies, specially Adialytus spp. and the spiders, can be useful controlling agents of the whitefly and aphids in cabbage.

2. Median temperature can increase the whitefly and thrips populations.

\section{Acknowledgements}

To the Brazilian government (Capes) and Universidade Federal de Viçosa, for the financial support; to Drs.
Antonio Domingos Brescovit, Ayr de Moura Bello, Celso Oliveira Azevedo, and Paulo Sérgio Fiúza Ferreira, for the identification of Aranae, Coleoptera, Hymenoptera, and Hemiptera, respectively.

\section{References}

BRODBECK, B.V.; STAVISKY, J.; FUNDERBURK, J.E.; ANDERSEN, P.C.; OLSON, S.M. Flower nitrogen status and populations of Frankliniella occidentalis feeding on Lycopersicon esculentum. Entomologia Experimentalis et Applicata, v.99, p.165-172, 2001.

CISNEROS, J.J.; GODFREY, L.D. Midseason pest status of the cotton aphid (Homoptera: Aphididae) in California cotton: is nitrogen a key factor? Environmental Entomology, v.30, p.501-510, 2001.

EIGENBRODE, S.D.; PILLAI, S.K. Neonate Plutella xylostella responses to surface wax components of a resistant cabbage (Brassica oleracea). Journal of Chemical Ecology, v.24, p.1611-1627, 1998.

FILGUEIRA, F.A.R. Novo manual de olericultura. Viçosa: UFV, 2000. 402p.

GONÇALVES, P.A.S. Flutuação populacional de tripes, Thrips tabaci Lind., em cebola em Ituporanga, Santa Catarina. Anais da Sociedade Entomológica do Brasil, v.26, p.365-369, 1997. 
HEINZ, K.M.; NELSON, J.M. Interspecific interactions among natural enemies of Bemisia in an inundative biological control program. Biological Control, v.6, p.384-393, 1996.

HOOKS, C.R.R.; VALENZUELA, H.R.; DEFRANK, J. Incidence of pests and arthropod natural enemies in zucchini grown with living mulches. Agriculture, Ecosystems and Environment, v.69, p.217231, 1998.

LEITE, G.L.D.; PICANÇO, M.; JHAM, G.N.; MOREIRA, M.D. Bemisia tabaci, Brevicoryne brassicae and Thrips tabaci abundance on Brassica oleracea var. acephala. Pesquisa Agropecuária Brasileira, v.40, p.197-202, 2005.

MARSCHNER, H. Mineral nutrition of higher plants. London: Academic Press, 1995. 889p.

MIRANDA, M.M.M.; PICANÇO, M.; LEITE, G.L.D.; ZANUNCIO, J.C.; CLERCQ, P. Sampling and non-action levels for predators and parasitoids of virus vectors and leaf miners of tomato plants in Brazil. Mededelingen Faculteit Landbouwwetenschappen Universiteit Gent, v.63, p.519-523, 1998.

NAKATA, T. Population fluctuations of aphids and their natural enemies on potato in Hokkaido, Japan. Applied Entomology and Zoology, v.30, p.129-138, 1995.

NEVO, E.; COLL, M. Effect of nitrogen fertilization on Aphis gossypii (Homoptera: Aphididae): variation in size, color and reproduction. Journal of Economic Entomology, v.94, p.27-32, 2001.
NOORTJE, B.C.; LINDHOUT, P. Resistance in Lycopersicon hirsutum f. glabratum to the greenhouse whitefly (Trialeurodes vaporiorum) increase with plant age. Euphytica, v.64, p.189-195, 1992.

PAULA, S.V.; PICANÇO, M.; KOGA, F.H.; MORÃES, J.C. Resistência de sete clones de couve comum a Brevicoryne brassicae (L.) (Homoptera: Aphididae). Anais da Sociedade Entomológica do Brasil, v.24, p.99-104, 1995.

SIMMONS, A.M. Oviposition on vegetables by Bemisia tabaci (Homoptera: Aleyrodidae): temporal and leaf surface factors. Environmental Entomology, v.23, p.381-389, 1999.

STANSLY, P.A.; SCHUSTER, D.J.; LIU, T.X. Apparent parasitism of Bemisia argentifolii (Homoptera: Aleyrodidae) by Aphelinidae (Hymenoptera) on vegetable crops and associated weeds in South Florida. Biological Control, v.9, p.49-57, 1997.

TAGASHIRA, E.; HIROSE, Y. Development and reproduction of Ceranisus menes (Hymenoptera: Eulophidae), a larval parasitoid of thrips: effects of two host species, Frankliniella intonsa and Thrips palmi (Thysanoptera: Thripidae). Applied Entomology and Zoology, v.36, p.237-241, 2001.

WOODHEAD, S.; CHAPMAN, R.F. Insect behaviour and the chemistry of plant surface waxes. In: JUNIPER, B.E.; SOUTHWOOD, T.R.E. (Ed.). Insect and the plant surface. London: E. Arnold, 1986. p.123-135.

Received on June 10, 2005 and accepted on August 15, 2006 